\title{
埼玉県草加市及び三郷市周辺における 小規模微動アレイ探査を用いた埋没谷地形の把握
}

\author{
林 宏 ${ }^{1} \cdot$ 稲崎富 $士^{2} \cdot$ 鈴木晴彦 1
}

Koichi Hayashi, Tomio Inazaki and Haruhiko Suzuki (2006) Buried incised-channels delineation using microtremor array measurements at Soka and Misato Cities in Saitama Prefecture. Bull. Geol. Surv. Japan, vol. 57(9/10), p.309 - 325, 17 figs.

\begin{abstract}
Microtremor array measurements (MAM) have been applied to delineate buried incisedchannels in urban area of Japan. The site is a rectangular of $6 \mathrm{~km} \times 4 \mathrm{~km}$ in the Nakagawa Lowland placed at Soka and Misato cities in Saitama prefecture, Japan. One-hundred and four MAM have been carried out to delineate buried incised-channels filled with unconsolidated alluvial deposits (Chusekiso) thicken about $50 \mathrm{~m}$. Triangle arrays were used at wide area, such as parks. L shaped arrays using roads and crossings were also used for the data acquisition at the most of the site. A spatial auto correlation (SPAC) method was applied to the approximately 10 minutes vertical component of microtremor data. Phase-velocity curves were calculated in the frequency range of between 2 and 10 Hz. In spite of cultural noise or irregular array shape, fundamental mode of phase-velocity curves are clearly obtained in the all observed points. An one-dimensional inversion using a non-linear least square method has been applied to the phase-velocity curves to obtain one-dimensional S-wave velocity structures. These one-dimensional structures were interpolated into a three-dimensional structure. We succeeded to map the shape and the depths of buried channel that agree with the borehole data very well. The reconstructed shape and the depths of buried incised-channel fit well with those interpreted from borehole data.
\end{abstract}

Keywords: Nakagawa Lowland, Holocene, Microtremor array measurements, Surface waves, Geophysical exploration

\section{要 旨}

埼玉県草加市及び三郷市周辺の中川低地において， 小規模微動アレイ探査により沖積層が厚く堆積してい る埋没谷の形状を地表から非破壊で求めることを試み た。テストフィールドは約 $6 \mathrm{~km} \times 4 \mathrm{~km}$ の長方形であ り, この範囲で 104 点の小規模微動アレイ探査を行っ た。公園などの開けた場所では正三角形のアレイを用 いたが，多くの点では道路脇や交差点などを用いた $\mathrm{L}$ 字型のアレイにより測定を行った。解析の結果, 自動 車などによる非定常な振動や, 非等方なアレイにも関 わらず, ほぼ全点において明瞭な分散曲線を求めるこ とができた。得られた分散曲線から逆解析により, 深 度 $70 \mathrm{~m}$ 程度までのS 波速度構造を求め埋没谷の形状を 推定した。得られた $\mathrm{S}$ 波速度構造及び埋没谷の形状は, PS検層結果や既存のボーリングデータなどから推定さ れる地盤構造と調和的であり，本手法の有効性を立証 することができた。

\section{1. はじめに}

都市域における，地表から深度 $100 \mathrm{~m}$ 程度までの地 盤構造は, 大深度地下利用に打ける支持層確認や, 地 震被害想定における地震動の増幅特性の推定など, 多 くの分野において大変重要である。

支持層確認のための地盤調査には通常はボーリング が行われるが, 都市域特有の問題として地表部の土地 利用が過密なため, 調査を行う範囲においてボーリン グ作業用の場所を確保できないことが想定される。こ のような場所に扎いてボーリングを補間するためには， 反射法地震探査など物理探査の利用が考えられている が, 過密な都市部では大掛かりな振源を使うことや測 線配置に制限を受けることが予想される。したがって， より簡便に地表から非破壊で地盤構造を求めることが できる手法の開発が望まれている。

地震時の地盤の増幅特性を評価する上で, $\mathrm{S}$ 波速度 $300 \sim 400 \mathrm{~m} / \mathrm{s}$ 程度以上のいわゆる工学的基盤(例えば 境ほか,2004)よりも浅部の速度構造は欠かせない。従

\footnotetext{
1応用地質株式会社 (OYO Corporation, Miyukigaoka 43, Tsukuba, 305-0841 Japan).

独立行政法人 土木研究所 (Public Works Research Institute, 1-6, Minamihara, Tsukuba, 305-8516, Japan).
} 
来, 地震時の地盤の増幅特性の評価には, 一般にボー リング孔を用いたPS検層によって測定された $\mathrm{S}$ 波速度 構造が用いられてきた。しかし，面的な地盤構造を把 握するためには, 多数のボーリングを実施する必要が あり，膨大な費用がかかる。地表から非破壊で深度数 $10 \mathrm{~m}$ までの地盤のS 波速度構造を簡便に求めることが できれば，ボーリングを行わなくても地盤の増幅特性 を計算することが可能となり，より精度の良い地震動 の予測が可能となる。 また, 最近の強震動観測や数值 解析により，表層地盤の不整形性が地震時の局所的な 地震動の増幅や被害に密接に関連していることがわ かってきた（例えば吉村ほか，2004）。したがって，精 度良く地震動による被害を予測するためには詳細な地 盤構造を面的に求めることが必要と考えられるように なっている。

そこで筆者らは, 都市域に打ける深度 $100 \mathrm{~m}$ 程度ま での地盤構造を地表から非破壊で求める手法として, 広い場所や大掛かりな振源を必要としない物理探査手 法である微動アレイ探査に着目した。微動アレイ探査 は地震波を用いた物理探査手法の一種であり，地盤の 常時微動を複数の地点で同時に測定することにより， 地盤の $\mathrm{S}$ 波速度構造を求める手法である。地盤の常時 微動は主に, 交通振動, 工場振動, 海岸線に押し寄せ る波動などを振動源として発生する表面波と考えられ て扣り，この表面波の伝播特性を解析することにより 地盤のS波速度構造を求めることができる（岡田・坂尻， 1983). 岡田ほか (1990) は, 主に長周期（周期 $1 \sim 10$ 秒）の常時微動を数 $10 \mathrm{~m}$ 〜数 $\mathrm{km}$ の大きなアレイを用 いて観測することにより，探査深度数 $10 \mathrm{~m}$ ～数 $\mathrm{km}$ の 深部地盤構造を求める方法を確立した。筆者らはより 短周期の常時微動（周期 $0.1 \sim 1$ 秒, 周波数 $1 \sim 10 \mathrm{~Hz}$ ) に対してこの手法を適用することにより，深度 $100 \mathrm{~m}$ 程度までの地盤構造を求めることも可能と考え, 数 $\mathrm{m}$ 〜数 $10 \mathrm{~m}$ の小規模なアレイを用いた微動アレイ探査の 適用性の研究を行っている（鈴木ほか, 2002）。

表面波を用いた物理探査手法として近年, 人工的に 起こした表面波を測定・解析する表面波探査 (Park et al., 1999; Hayashi and Suzuki, 2004）が，河川堤防調 査や住宅地盤調查など様々な地盤調查へ適用されるよ うになってきた（林・鈴木，2003；Hayashi et al., 2005).しかし表面波探査では, 表面波の励起にカケヤ (大きな木製のハンマー) などを用いた場合, その探査 深度は $10 \mathrm{~m}$ 程度であり, 重鍾落下などを用いても探査 深度は $20 \mathrm{~m}$ ほどである。したがって, 大深度地下利用 における支持層確認や地震動の増幅度特性を計算する ための調査手法としては, 探査可能深度が浅すぎる。 表面波探査に打いてより探査深度を大きくするために は, 受振器間隔を広げて低い周波数の波を取得する必 要があるが, このためにはより大きな振源と長い測線
を設置可能な広い測定場所が必要となり, 手法の簡便 性が失われてしまう。しかし, 小規模な微動アレイ探 査により深度 $100 \mathrm{~m}$ 程度までの探査が可能になれば, 表面波探査と組み合わせることにより, 地表から深度 $100 \mathrm{~m}$ 程度まで簡便に調査を行うことができる。

以上のように, 小規模微動アレイ探査が実用化すれ ば都市域の地盤調查手法として大変有効と思われる。 そこで, 都市域に扎いて詳細な地盤構造がわかってい る, 埼玉県の草加市と三郷市付近 (石原ほか, 2004) で 小規模微動アレイ探査を行い,その適用性を検証した。

\section{2. 調查地の概要}

産業技術総合研究所は, 平成 14 年度から沖積平野に 広がる大都市の防災・環境保全・再生に資することを 目的として, 沖積層の三次元的な地質モデルとデータ ベースの構築, そして堆積環境とその工学的特性を明 らかにする総合的な研究プロジェクトを行っている (木村, 2004)。その一環として, 平成 15 年度から関東 地方の埼玉県南東部, 特に草加市そうか公園周辺をテ ストフィールドとして, 中川低地を構成する沖積層下 に伏在する埋没谷及び埋没段丘の形状の詳細把握(中西 ほか, 準備中), 沖積層不整形性が地震動に与える影響 の評価を目的とした稠密アレイ強震動観測などを実施 している. 本テストフィールドが位置する中川低地は, 1923 年の関東地震の際に周りに比べて被害が大きく, ごく最近まで利根川の分岐河川が集合する地域でも あったことから, 地盤条件と地震動による被害の関係 も議論されている地域である（武村・諸井, 2002 ; 諸井・ 武村, 2002)。本テストフィールドでは, 産業技術総合 研究所により多くの既存ボーリングのデータが集めら れており，詳細な基盤の深度分布がまとめられている (中西ほか, 準備中)。本論文では以下, 基盤とは沖積 層下面（ただし基底礫層が存在する場合はその上面） を意味し，一般に $\mathrm{S}$ 波速度 $300 \sim 400 \mathrm{~m} / \mathrm{s}$ 以上, $\mathrm{N}$ 值 25 (粘土) 〜 50 (砂) 以上を目安とする（例えば日本道路 協会, 1996)。 また, テストフィールド内の柿木浄水場 のボーリング孔（GS-SK-1）ではPS検層も行われてお り,地盤のS波速度構造が得られている。このようなこ とから, 本テストフィールド内で小規模微動アレイ探 査を行うことにより，都市域に打ける地盤構造調査と しての同手法の有効性を検証することができる。

第1困に調查地及び小規模微動アレイ探査の測定地点 を示す。調查地は埼玉県の草加市から三郷市にかけて の東西約 $6 \mathrm{~km}$, 南北約 $4 \mathrm{~km}$ の範囲であり, 現在の標 高は2〜 4 とほぼ平坦である。遠藤ほか (1988) や石原 ほか（2004）によれば, 調査地中心を北から南に流れ る中川沿いに幅 $2 \sim 3 \mathrm{~km}$ の埋没谷が存在し, その東西 は埋没段丘となっていると考えられている（沖積層の 


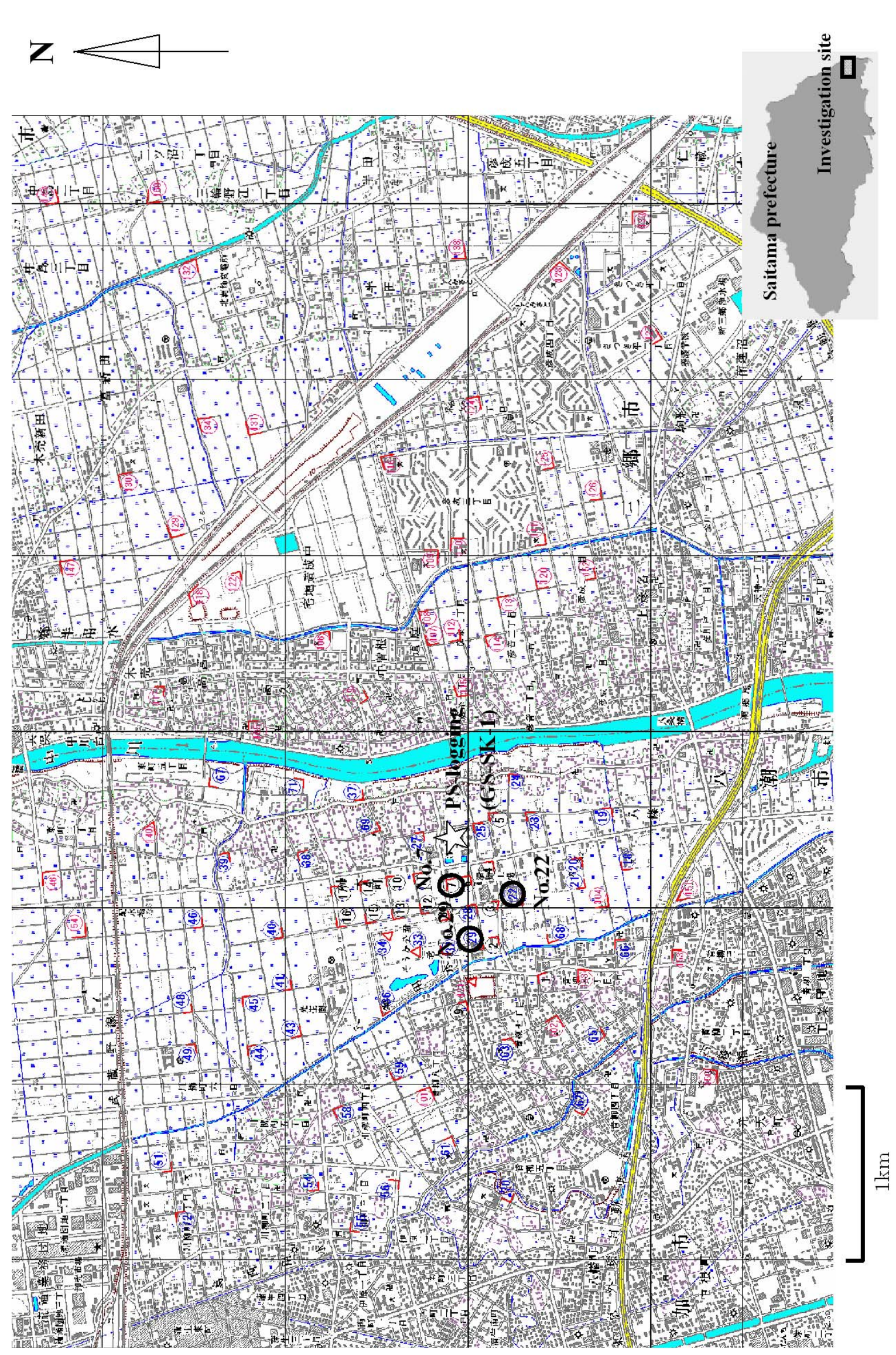

椣 气

臣

+ क

N

II $\sum$ 的

m

느

จ

+6

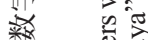

保

粠

II)

11 प

효요

ก कำ

然

然

흥

佂

II

m $\sum$

4 in

ถั่

+o 40

乘

整

퍄

to

业 气气

से च्चु

$\leftarrow \quad$ 啳

$\neq \quad$ क

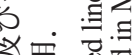

需递

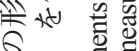

不

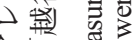

to

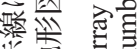

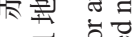

U.

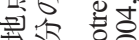

竞

帚的数

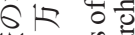

烟等

装

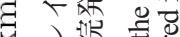

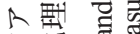

鱼语氙

焉

四

迸要

政

需硐吕言

区

紫 


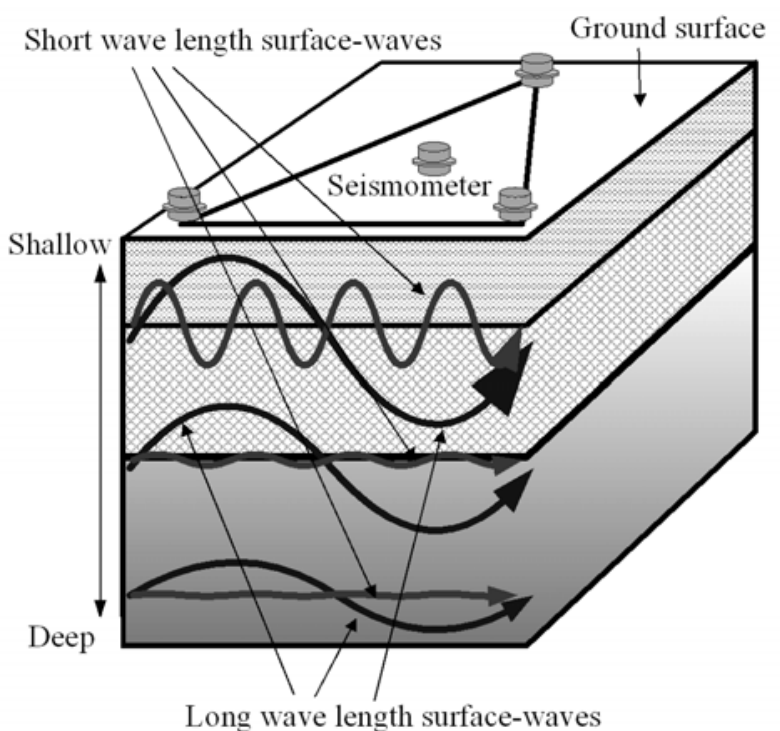

第2困 微動アレイ探査の概念図. 短い波長の表面波は深度 とともに急速に振幅が小さくなるのに対して，長い 波長の表面波は深い深度でも大きな振幅を保ってい る。このことから，短い波長の表面波は主に地表付 近のS 波速度を反映し，長い波長の表面波は深部の $\mathrm{S}$ 波速度構造も反映する. 異なる周波数 (波長)の表 面波の位相速度を測定することにより，地盤の S 波 速度の深度による違いを推定することができる。

Fig. 2 Schematic diagram showing microtremor array measurements. Amplitudes of shorter wave length surface-waves decay rapidly with depth whereas those of longer wave length keep amplitude even if deeper part. Therefore, shorter wave-length surface-waves reflect shallow S-wave velocity and longer ones reflect deeper S-wave velocity. S-wave velocity profile can be estimated be measuring phasevelocity for different wave-length (frequency).

下面深度は, 埋没谷では深度 40 ～50 m, 埋没段丘では 深度 20 ３0 m となっている).

\section{3. 小規模微動アレイ探査}

\section{1 微動アレイ探查の概要}

地表面は波や風など自然現象や交通振動などにより 常に振動している。これは常時微動と呼ばれるが,その 波動は地震波 (弾性波)の一種である表面波が大部分を 占めると考えられている．表面波には,鉛直方向及び水 平方向 (振動の伝播方向) に振動するレイリー波と, 水 平方向 (振動の伝播方向に直交する方向)に振動するラ ブ波がある。地盤を伝わる表面波の伝播速度は主に地 盤のS波速度構造を反映するので,表面波の伝播特性を 解析することにより地盤のS波速度構造を推定すること ができる (林, 2004)。複数の地震計で常時微動を測定 し，只の伝播特性を解析することにより地盤のS波速度 を求める物理探査技術が微動アレイ探査である.

地盤のS波速度が深度方向に異なる場合, 表面波の
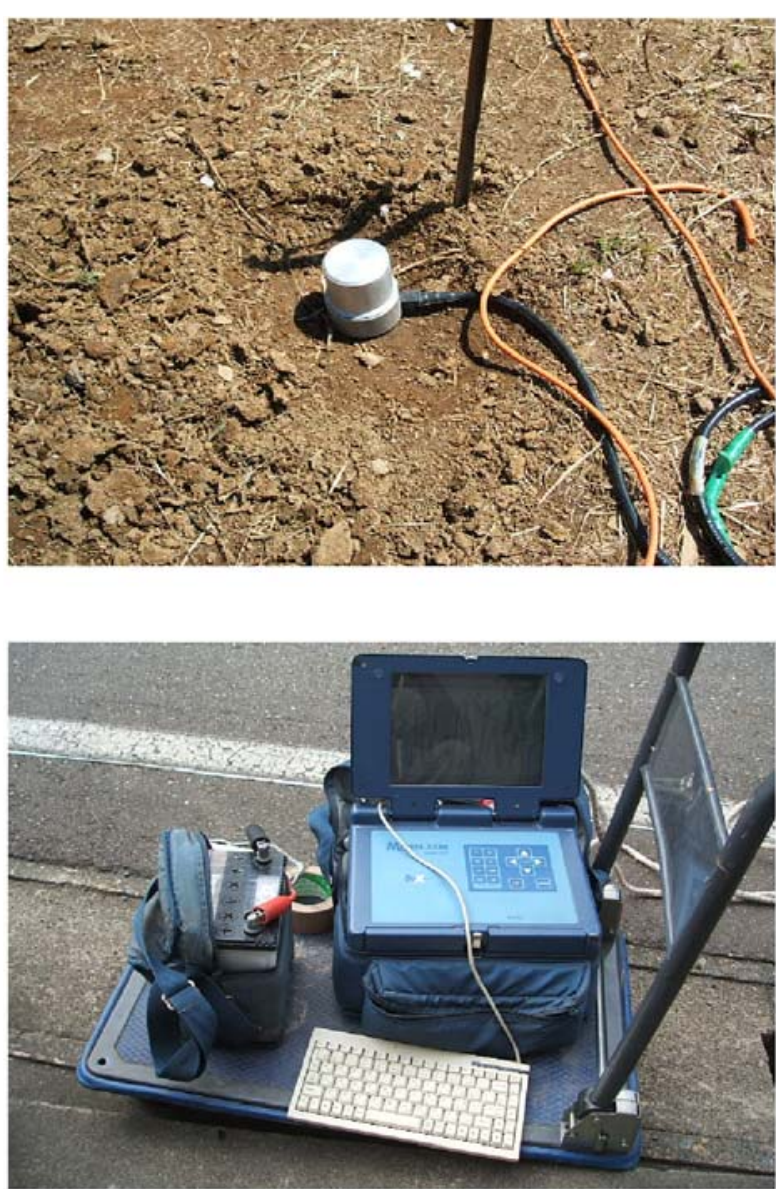

第3図 微動アレイ探査の測定に用いた地震計（上）と測定 器 (下).

Fig. 3 A seismometer (top) and a seismograph (bottom) used in the data acquisition of microtremor array measurements.

伝播速度は周波数（波長）によって異なる. 各周波数 に打ける伝播速度を位相速度と呼び, 周波数に対して 位相速度をプロットしたものを分散曲線と呼ぶ。分散 曲線を逆解析することにより地盤のS 波速度構造を求 めることができる。したがって, 常時微動が表面波で あれば，その位相速度を測定することにより表面波探 查の原理を用いて地盤の $\mathrm{S}$ 波速度構造を求めることが できる(岡田ほか, 1990)。第2図に微動アレイ探査の 概念を示す。

常時微動のうち水平方向の振動にはレイリー波とラ ブ波の両方が含まれているので扱いが難しくなるが， 鉛直方向の振動にはレイリー波のみが含まれていると 考えることができるので比較的容易に解析することが できる。したがって, 一般に微動アレイ探査では常時 微動の鉛直方向の振動を測定し, これをレイリー波と 仮定して解析を行う (岡田ほか, 1990)。以下, 表面波 はレイリー波のことを意味する。

本論文に扔いて, 測定に用いた受振器は固有周波数 
$2 \mathrm{~Hz}$ の上下動地震計, 測定器は応用地質社製の McSEIS-SXWである。第3図に使用した地震計及び測 定器の写真を示す。受振器は多芯ヶーブルを介して測 定器に接続した。測定器のチャンネル数は 24 であり, 1 台の測定器で接続した全ての受振器の波形を同時に収 録することができる。サンプリング間隔は $2 \mathrm{msec}$ で, 一つのファイルに 16,384 サンプルのデータを収録した. したがって一つのファイルの記録時間は約 32 秒であ る。このようなファイルを 1 地点で 20 個収録した。し たがって 1 地点における記録時間は合計約 10 分である.

\section{2 空間自己相関関数法}

常時微動の位相速度を決定するためには，その伝播 方向を知る必要があるが，常時微動は複数の方向から 到来するために，伝播方向を決定することは難しい. そこで受振器を第2罒に示したように面的に配置し, 空 間自己相関関数法 (Aki, 1957) と呼ばれる統計的な処 理を行うことにより，常時微動，すなわち表面波の位 相速度を決定する。Aki (1957) による空間自己相関関 数法による波形データの解析は, 以下のようにまとめ られる。

まず,任意の二つの波形 $f(t)$ 及び $g(t)$ のフーリエ変換 をそれぞれ $F(\omega), G(\omega)$ とした時，そのクロスコリレー ション $C C_{f g}(\omega)$ は下記のように計算される。

$$
C C_{f g}(\omega)=F(\omega) \cdot \overline{G(\omega)}=A_{f}(\omega) A_{g}(\omega) \cdot \exp ^{i \Delta \phi(\omega)}
$$

ここで, $A_{f}(\omega), A_{g}(\omega)$ はそれぞれ $F(\omega), G(\omega)$ の振幅, $D f(\omega)$ は二つの波形の位相差である。二つのトレース の複素コヒーレンス $\mathrm{COH}_{f g}(\omega)$ は下記のように定義さ れる。

$$
C O H_{f g}(\omega)=\frac{C C_{f g}(\omega)}{A_{f}(\omega) A_{g}(\omega)}
$$

空間自己相関関数 $(S P A C)$ は複素コヒーレンスの方 位平均であり, 受振器の間隔 $r$ と周波数 $\omega$ の関数として 下記のように定義される。

$$
\operatorname{SPAC}(r, \omega)=\frac{1}{2 \pi} \int_{\varphi=0}^{\varphi=2 \pi} \operatorname{COH}(r, \varphi, \omega) d \varphi
$$

ここで, $\varphi$ は二つの受振器が位置する直線の角度で あり，(3) 式は角度 $\varphi$ の方位で $r$ の間隔を持つ二つの受
振器から計算した複素コヒーレンスを, 全方位に対し て平均することを意味する。空間自己相関関数の実数 部は下記のように零次のベッセル関数となる.

$$
\operatorname{Re}(\operatorname{SPAC}(r, \omega))=J_{0}\left(\frac{\omega}{c(\omega)} r\right)
$$

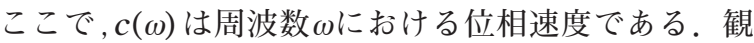
測によって得られるのは (4) 式の左辺であるので, 各 周波数について位相速度 $c(\omega)$ を変えながら右辺のべッ セル関数を計算し, 両辺の差が最も小さくなる速度を その周波数の位相速度とする。

(3) 式で示される空間自己相関関数は, 円形や正三 角形のような等方なアレイについて計算できるもので あり, 直線や L 字型アレイのような等方ではない配置 の場合には (3) 式の方位平均は計算できない。しかし， 仮に常時微動が特定の伝播方向を持たずに全ての方向 から均等に到来していれば, 受振器アレイは非等方で も（3）式の方位平均を計算することができる。ある程 度長い時間の微動を平均すれば, 様々な伝播方向の微 動を含むことにより正しく方位平均を計算できる可能 性がある。そこで, 本論文では, 受振点間隔の等しい 複素コヒーレンス関数をファイル数分平均することに より空間自己相関関数とした。

\section{3 非等方アレイの実験例}

前述のように空間自己相関関数法では，常時微動が 限られた方向からのみ到来していても, 受振器アレイ が円形など空間的に等方な形状であれば (3) 式の方位 平均は計算できる。常時微動がどのような方向から来 ているかはわからないので, 通常は正三角形など円形 に近い形状で測定を行う。しかし, 地表部の土地利用 が過密な都市域では, 円形や正三角形のアレイを配置 することは難しい場合も多い。そこで, 円形や正三角 形ではなく、直線や L 字型などの非等方な形状のアレ イを用いることを考える. Louie (2001) は, 直線アレ イであっても周波数 $1 \sim 10 \mathrm{~Hz}$ 程度の短周期であれば， 常時微動から求めた位相速度を用いて地盤のS波速度構 造を推定できることを示した。 L字型や直線のアレイが 適用できれば, 都市域であっても道路と交差点を利用 することにより小規模微動アレイ探査を実施すること が可能となる。

等方ではないアレイの適用性を検証するために，同 一の場所で異なる形状のアレイで測定を行い，その分 散曲線を比較した。調査地はイタリアのピサ市にある ピサの斜塔地内であり測定は平成 15 年に行った。測定 を行ったアレイは,第4図に示した円形, 正三角形, L 字型の三種類であり約 10 分間のデータを取得した。 L 字型のアレイを用いることができれば，都市域でも交 

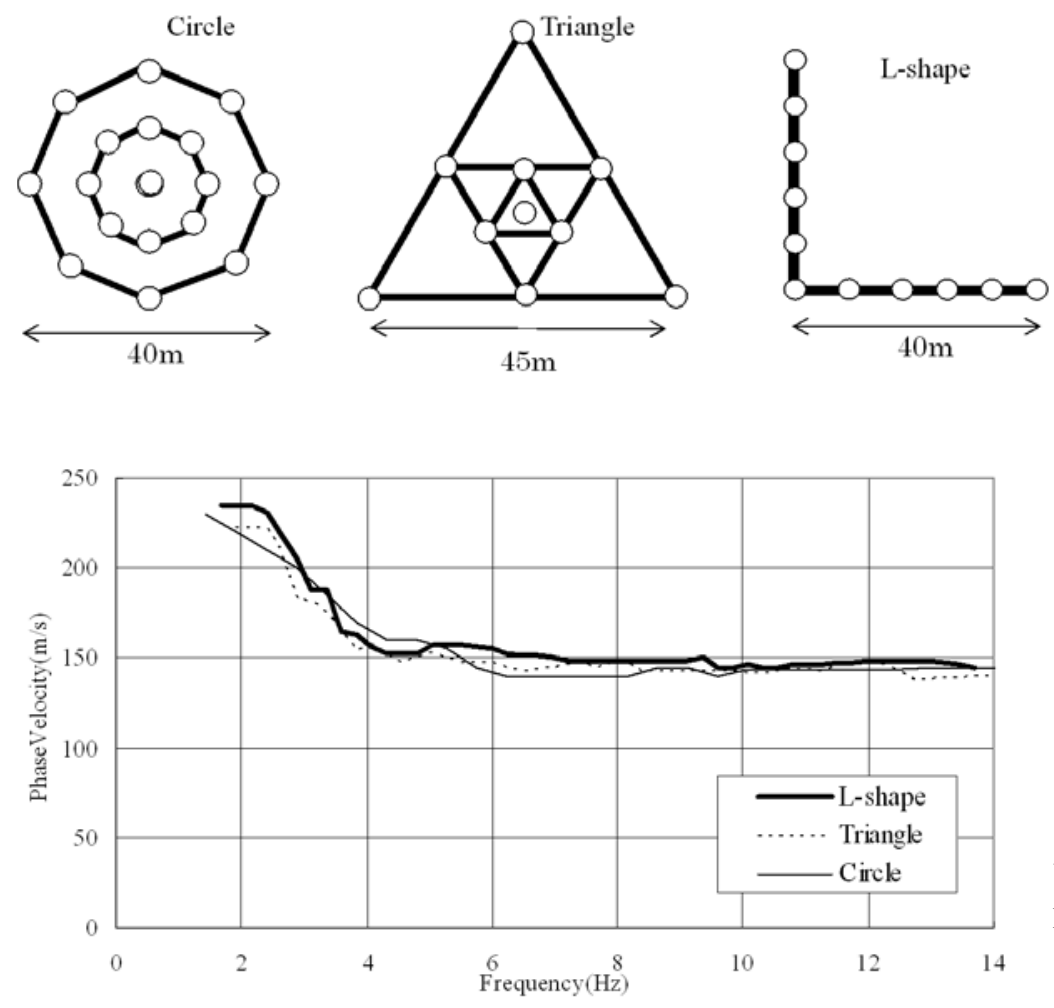

差点などを利用して測定を行うことができる，第5困に 得られた分散曲線を示す。ほぼ同じ分散曲線が得られ て扣り，アレイの形状によって位相速度は変わらない ことがわかる。筆者らは同じような実験を多くの場所 で行ったが，ほぼ全ての実験でアレイの形状によらず 同じ分散曲線が得られた。このことは，対象としてい る周波数 $1 \sim 10 \mathrm{~Hz}$ の常時微動は, 10 分程度の記録を平 均すれば，特定の方向ではなく多くの方向から到来し ていると考えられる。したがって, 周波数 $1 \sim 10 \mathrm{~Hz}$ 程 度の短周期の微動アレイ探査では, $\mathrm{L}$ 字型のアレイでも 正しい分散曲線を測定することが可能と思われる。

近年、横井ほか（2006）は理論的な検討及び現場実 験をとおして, $\mathrm{L}$ 字型アレイや直線など非等方なアレイ であっても，使用する波数の範囲を制限すれば，実用 上問題ない程度の精度で位相速度を決定できることを 示した。本節で示した実験結果も非等方なアレイの適 用性を示しており，短周期の微動アレイ探査では等方 なアレイを設置することができない都市域においても， 非等方なアレイを用いて実用上問題ない精度で探査を 行うことが可能と考えられる。

\section{4. 草加市及び三郷市周辺における測定及び解析}

測定は, 平成 15 年度から平成 17 年度の 3 年間にわ たって行い，そうか公園の周囲から次第に調查範囲を
第4図 比較を行ったアレイの形状とサイズ.

(a) Circle , (b) Triangle, (c) L-shaped とする。

Fig. 4 Shape and size of arrays used in the comparison.

(a) Circle , (b) Triangle, (c) L-shaped.
第5図 異なるアレイ形状による分散曲線の比較.

Fig. 5 Comparison of dispersion curves obtained through different array shape.

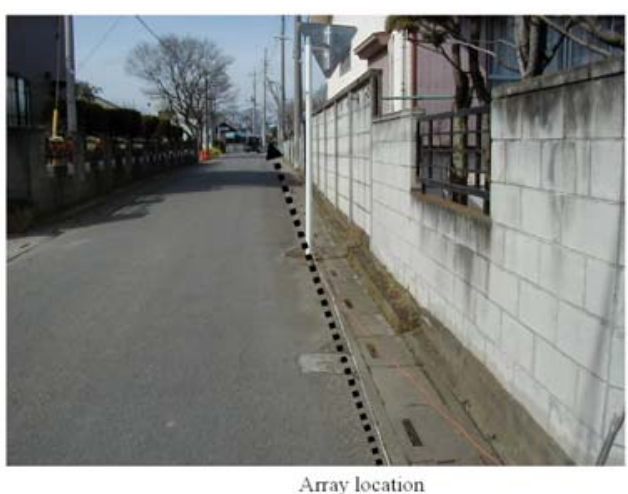

Array location

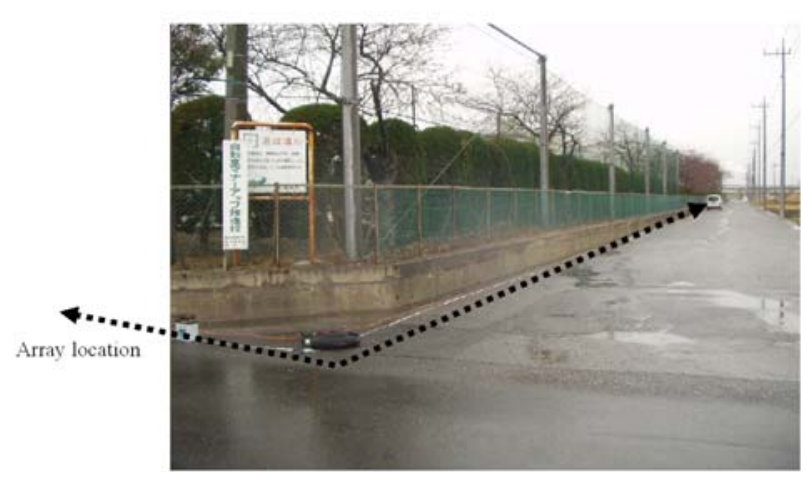

第6図 道路沿いに設置した L 字型アレイの状況.

Fig. 6 L-shaped array along a road. 


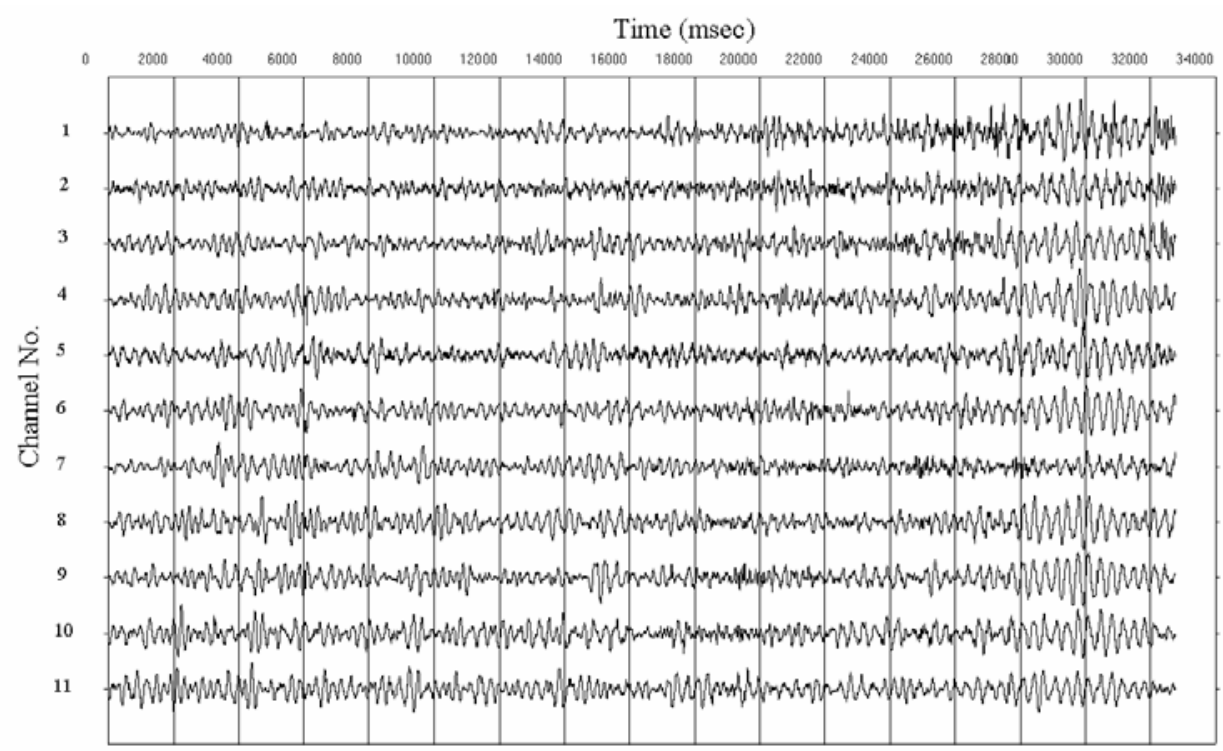

No.22

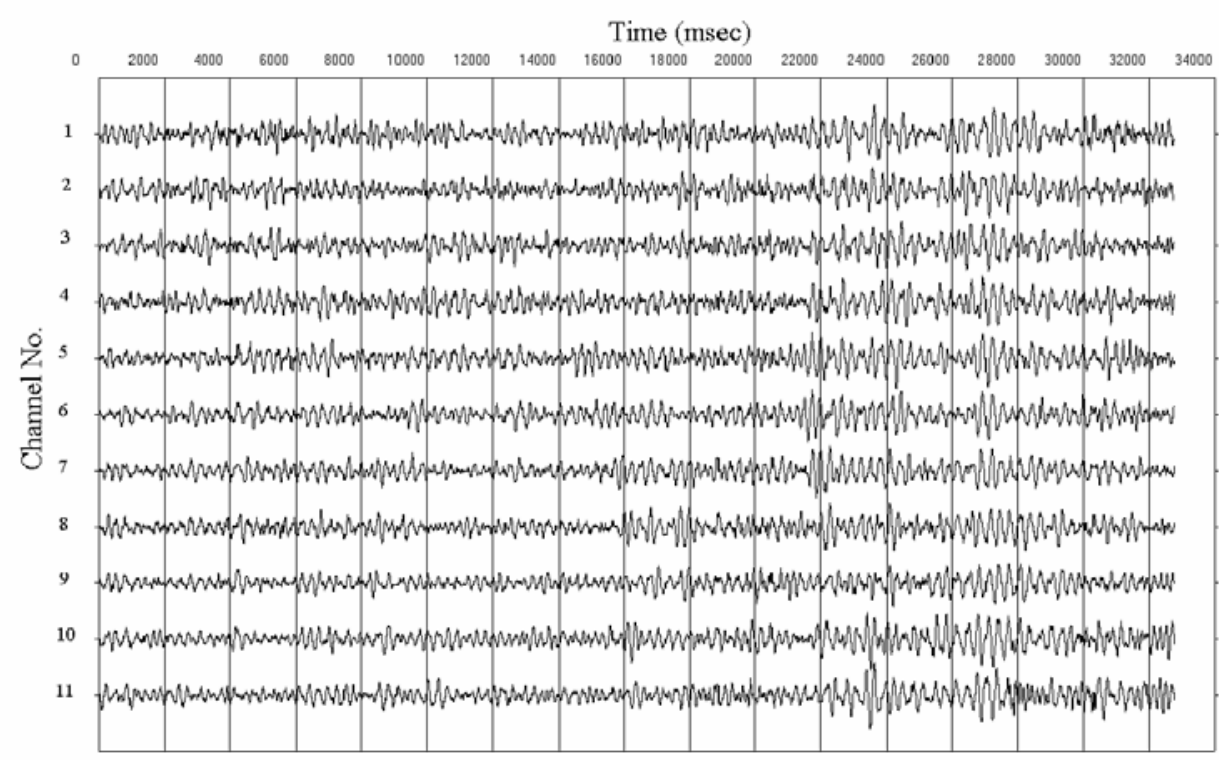

No.29

第7圾埋没谷内の No.22（上）と埋没段丘上のNo.29（下）で得られた測定波形記録例.

Fig. 7 Example of waveform data obtained at buried channel (No.22 : top) and buried terrace (No.29: bottom).

広げるように測定した (第1罒)，測定点数は計 104 点 である。

公園やグランドなどの広い場所で測定を行うことが できた 3 地点 (No.33，34，121）では，10個の地震計 を用いた正三角形アレイ（第4罒）により測定を行っ た。その他の地点では, 交差点などを利用して道路脇 に11個の地震計をL字型（第4図右）に配置して測定し た。第6図にL字アレイの設置状況の写真を示す。アレ イのサイズ（一辺の長さ）は $40 〜 75 \mathrm{~m}$ である. 1地点
の測定に要した時間は約1時間であった。測定は3班で 行い, 一つの班が 1 日に測定した地点の数は $4 \sim 6$ 点で ある。一つの班の測定員人数は 2 人もしくは 3 人であ る。測定に要した日数は 3 年間で計 9 日である.

第7罒に, 埋没谷内と思われるNo.22 と埋没段丘上と 思われるNo.29の測定点で得られた波形記録例を示す。 記録長は約 32 秒であり,このような波形ファイルを各測 定点に打いて 20 個取得した。第8図に 20 個の記録(約 10 分)から計算した同じ地点の振幅スペクトルを示す。両 


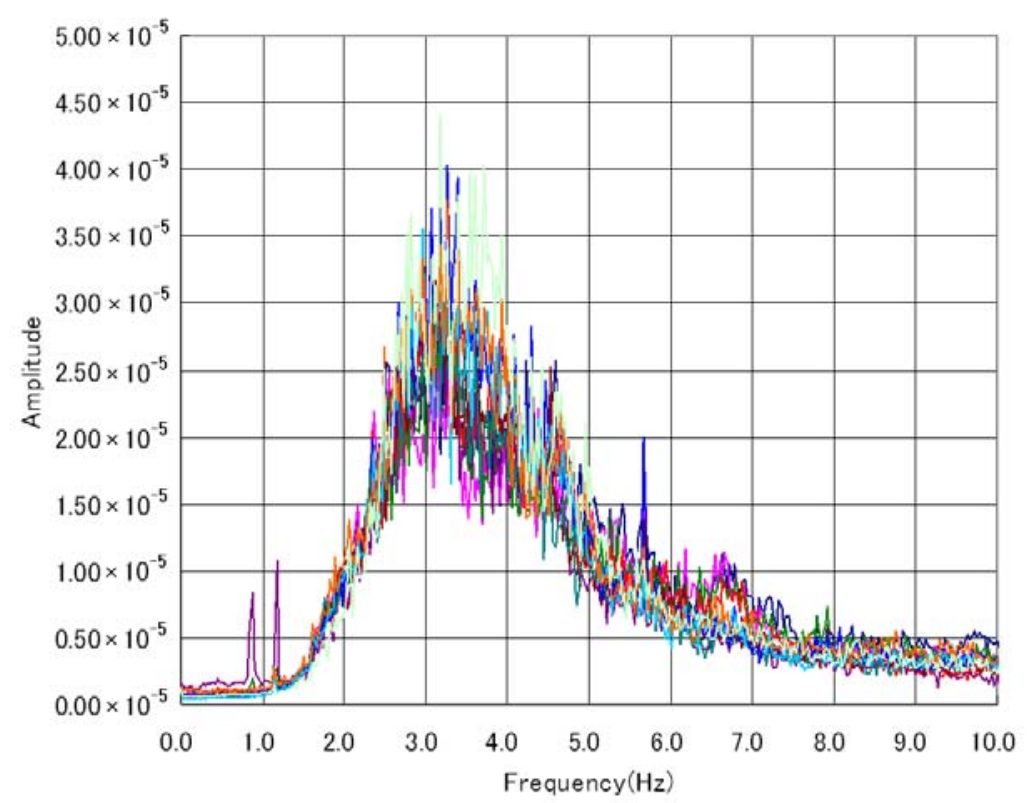

Channel No.

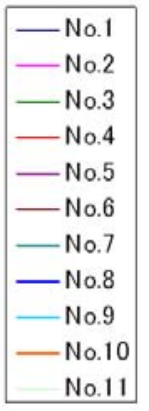

No.22

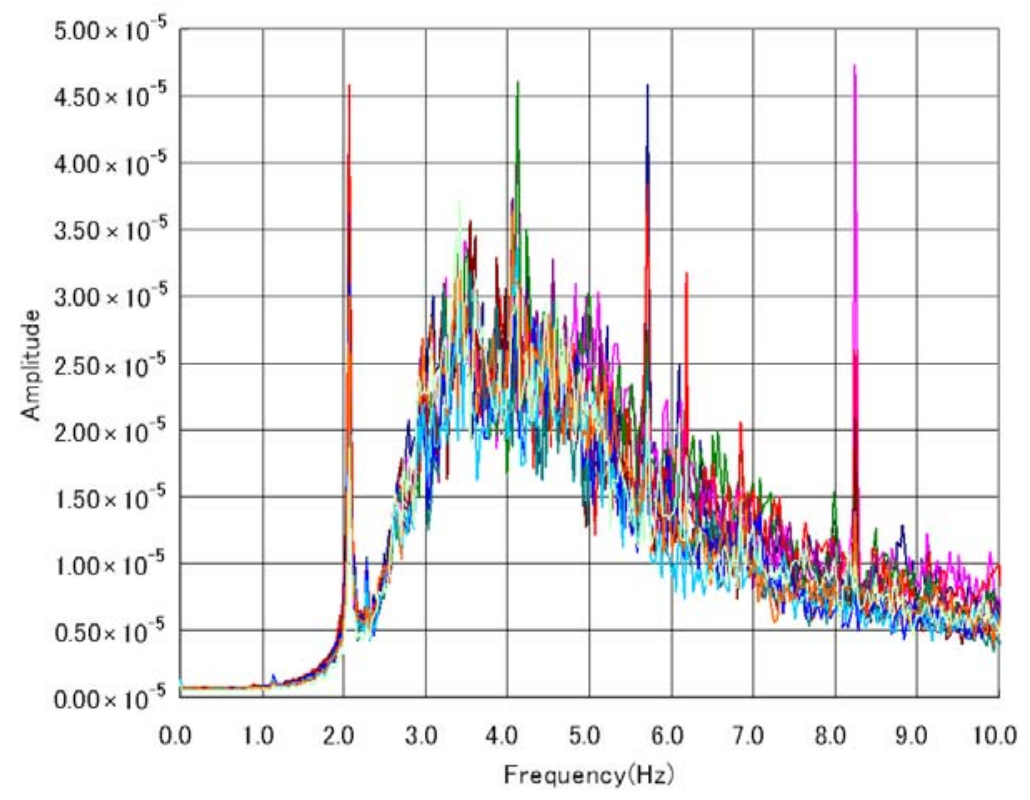

Channel No.

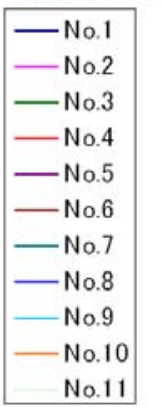

第8図 埋没谷内の No.22（上）と埋没段丘上のNo.29（下）で得られた振幅スペクトル.

Fig. 8 Amplitude spectrum obtained at buried channel (No.22 : top) and buried terrace (No.29: bottom).

地点の記録を比べると,波形記録でも振幅スペクトルで も顕著な差は見られないことがわかる．

第9罒にNo.22及びNo.29の測定点で得られた空間自己 相関関数の実数部を周波数に対して示す. 両地点とも空 間自己相関関数は三角関数のような波形であるが、周波 数 $2 \mathrm{~Hz}$ 程度よりも高周波数側では次第に振幅が小さく なっておりべッセル関数状となっていることがわかる.

このような空間自己相関関数に対して，同一の周波 数で受振点距離が違う関数を抜き出し，(4) 式により
位相速度を変えながらベッセル関数を計算して観測值 (空間自己相関関数) と比較した。第 10 図にNo.22 と No.29の 2 地点について, $2.28 \mathrm{~Hz}$ における空間自己相 関関数と, 残差が最も小さくなる位相速度に対する理 論的なべッセル関数を示す。このように各周波数につ いて, 位相速度を変えながらべッセル関数と空間自己 相関関数の残差を計算し, 残差が最も小さくなる速度 をその周波数の位相速度とした. 第11罒は, 空間自己 相関関数とべッセル関数の残差の分布を色の違いで表 


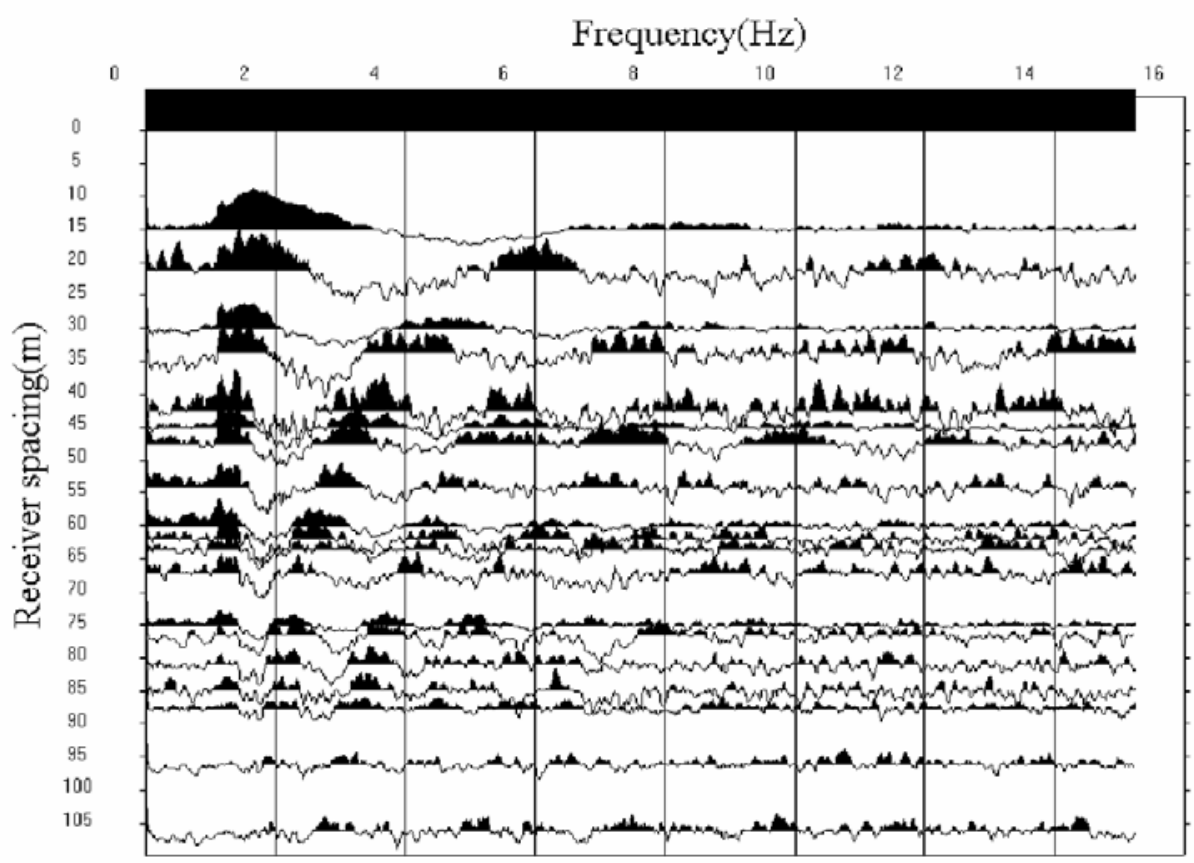

No.22

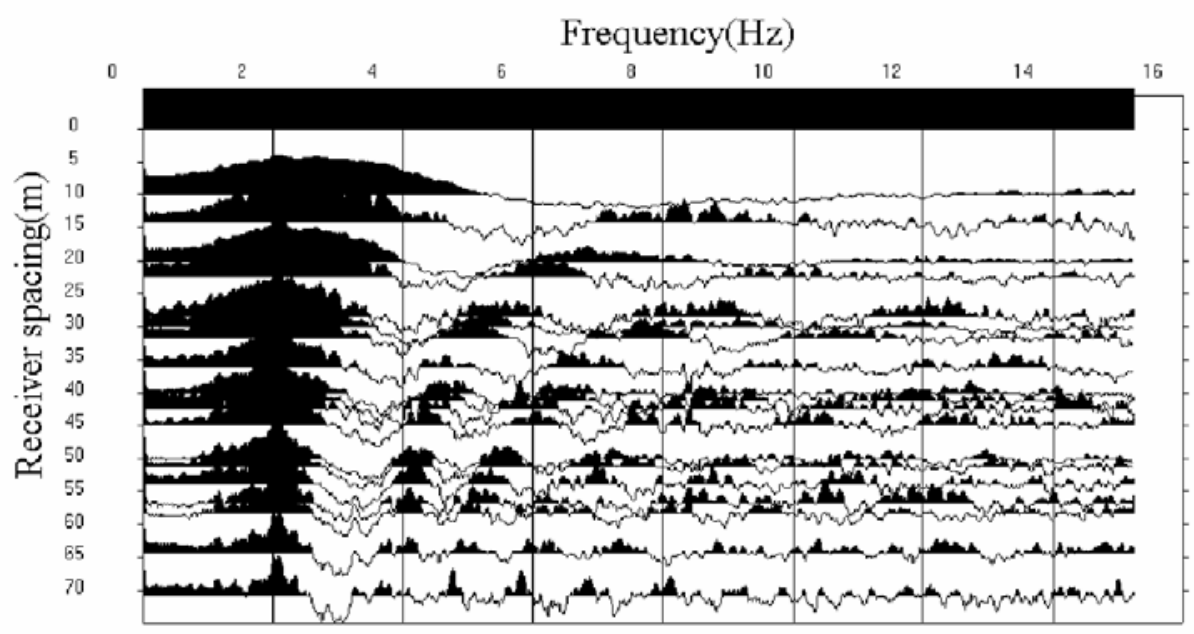

No.29

第9図 埋没谷内の No.22（上）と埋没段丘上の No.29（下）で得られた空間自己相関関数の実数部.

Fig. 9 Real part of spatial auto correlation obtained at buried channel (No.22 : top) and buried terrace (No.29 : bottom).

現したものであり，青色の部分は残差が小さいことを 示す. No.22では周波数 $1.5 \sim 6.5 \mathrm{~Hz}$ の範囲で, No.29 では周波数 $2 \sim 9 \mathrm{~Hz}$ の範囲で明瞭な分散曲線が見られ ることがわかる。第11図の各周波数において残差の最 も小さい位相速度を読み取ることにより求めた分散曲 線を第 12 図に示す。埋没谷内と思われるNo. 22 と埋没 段丘上と思われるNo.29で，明らかに分散曲線が異な ることがわかる。このように分散曲線に明らかに差が あることは, 埋没段丘上と埋没谷内のS波速度構造に大
きな差があることを示唆する。以上のような解析を， 全ての地点で得られた波形データに対して行った。第 13 図に, 測定を行った全ての地点において得られた分 散曲線を示す。

これらの分散曲線から, 逐次線形化非線形最小二乗 法により S波速度構造を求めた（Xia et al., 1999）。表 面波の分散曲線の解析において, その位相速度は対応 する波長の打打むね $1 / 3$ 程度の深度までの地盤のS 波速 度の平均に近いことが一般に知られている。したがっ 

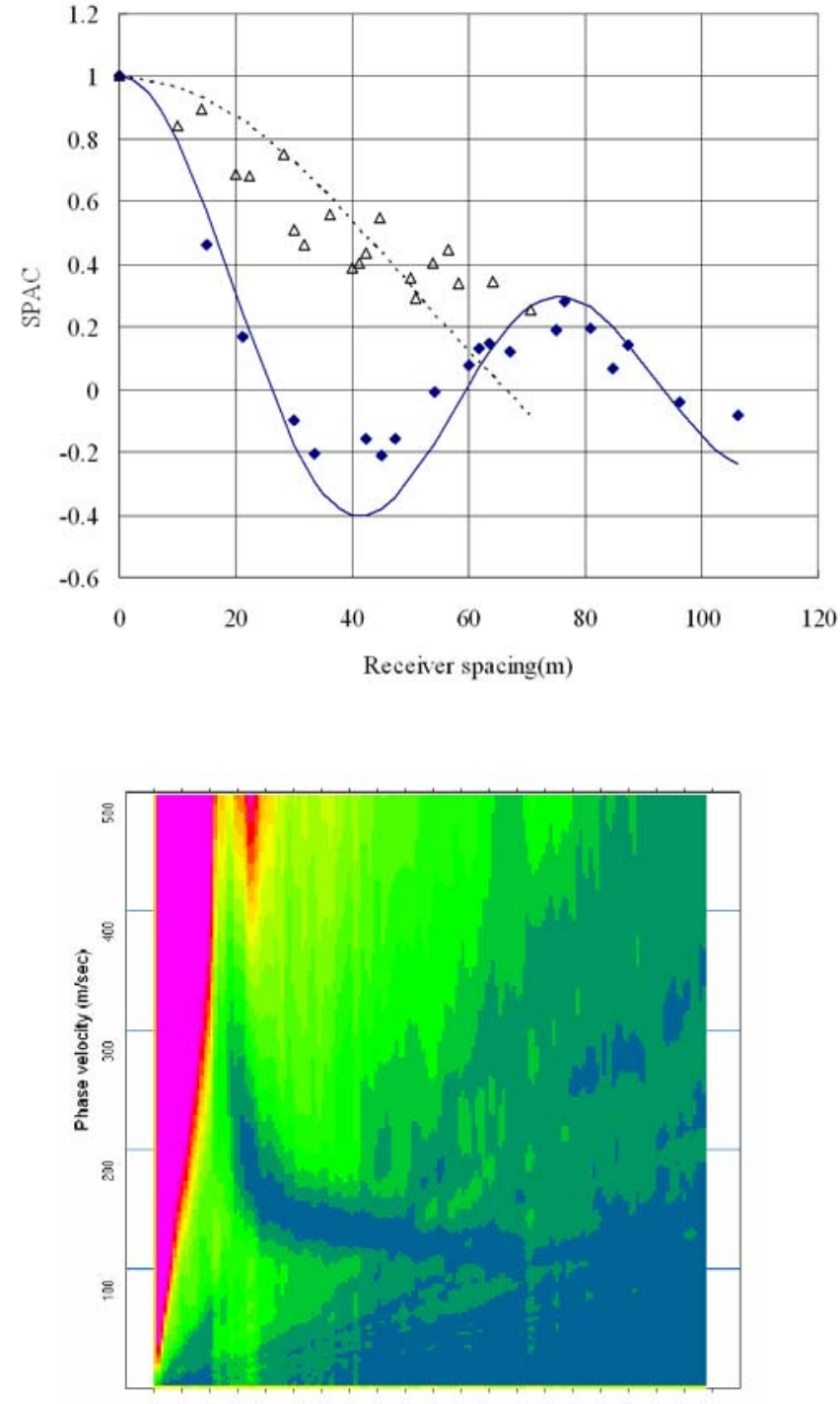

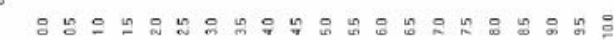
Frequency (Hz)

No.22
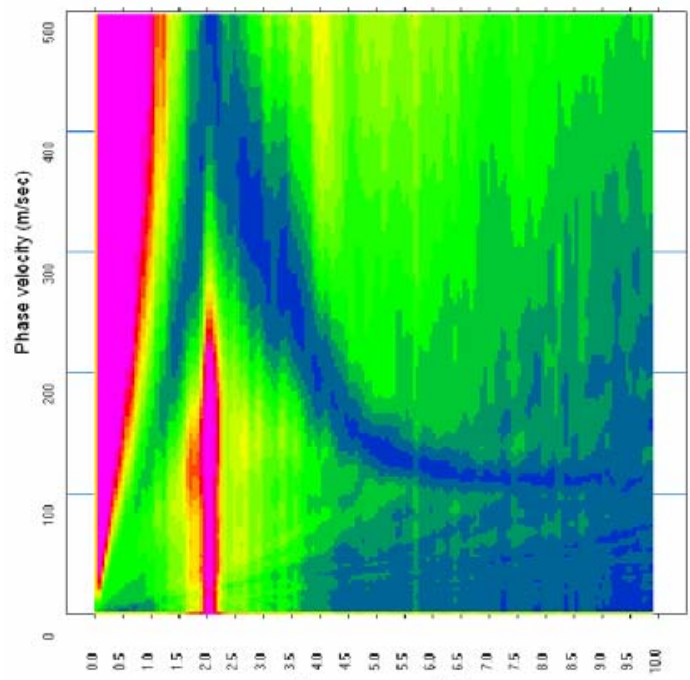

Frequency (Hz)

No.29

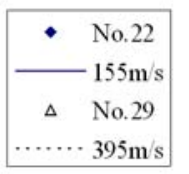

第 10 図 観測波形から計算された $2.28 \mathrm{~Hz}$ にお ける空間自己相関関数 (SPAC) の值 (菱形及び三角形) と, 残差が最も小さ くなる位相速度に対する理論的なべッ セル関数（実線及び破線）。

Fig. 10 Spatial auto-correlation (SPAC) for $2.28 \mathrm{~Hz}$ calculated from observed waveform data and theoretical Bessel functions for the phase velocity that minimize the residual between spatial auto-correlation and Bessel function.

て初期モデルは, 分散曲線の周波数と位相速度を波長 に換算し，波長の $1 / 3$ を深度に位相速度をプロットす ることにより作成した。この初期モデルに対してコン パウンド・マトリックス法（齋藤・椛沢，1993）によ り理論的な分散曲線を計算し, 観測分散曲線との残差 が小さくなるように最小二乗法によりモデルを修正す る.この理論分散曲線の計算とモデルの修正を, 残差 が十分小さくなるまで繰り返す。第14罒に, 第 12 図に 示したNo.22及びNo.29の分散曲線から得られた $\mathrm{S}$ 波速 度構造を示す。埋没段丘上と埋没谷内で大きく $\mathrm{S}$ 波速度 構造が異なることがわかる。第15図に, 柿木浄水場の ボーリング (GS-SK-1) で行ったサスペンションPS検 層の結果 ( $\mathrm{S}$ 波速度) とその近傍に扎いて行った微動ア レイ探查の解析結果 (No.7) を示す。深度 15 ～ $20 \mathrm{~m}$ に 存在する高速度の挟み層 (砂層) や, 深度 $50 \mathrm{~m}$ 付近の 基盤（基底鿬層の上面）に対応する速度境界は十分に 再現できていないが, 打打むね正しいS波速度が得られ ていることがわかる.なお第 15 図に扎いて, 深度 $50 \mathrm{~m}$ 以深では微動アレイ探査から得られた $\mathrm{S}$ 波速度はPS検 層の結果と比較して有意に低い。この理由は, 微動ア レイ探査では使用した測定器の限界やアレイの大きさ などにより, 深部 (本調查地では深度 $50 \mathrm{~m}$ 以深) では 速度の決定精度が低いためであり, 本論文で用いた解 析手法では, 精度の低い深部のS 波速度構造は低めに求 まっている可能性がある。以下, 微動アレイ探查の解

$\leftarrow$

第11図 埋没谷内の No.22（上）と埋没段丘上の No.29 (下) における,空間自己相関関数とベッセル関数の残差 の分布．青色の部分は残差が小さいことを示す。

Fig. 11 Residual between spatial auto-correlation and Bessel function at buried channel (No.22: top) and buried terrace (No.29: bottom). Blue color indicates that the residual is relatively small. 


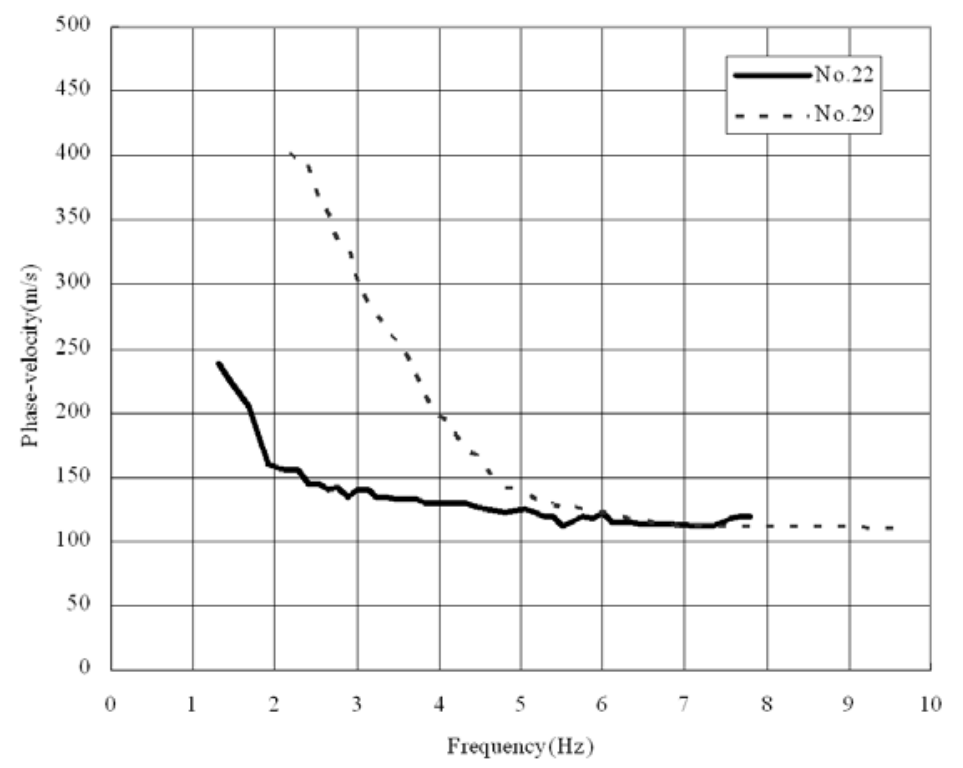

第 12 図埋没谷内の No.22（実線）と埋没段丘上の No.29 (破線) の分散曲線の比較.

Fig. 12 Comparison of dispersion curves obtained at buried channel (No.22: top) and buried terrace (No.29: bottom).
析結果と既存ボーリングから求められた地盤構造を比 較するが, 基盤の深い埋没谷においては, $\mathrm{S}$ 波速度が低 めに求まっている可能性があることに留意されたい.

\section{5. 調查地の基盤深度分布}

以上のようにして各測定地点に打いて深度 $70 \mathrm{~m}$ 程度 までのS波速度構造を求め,これを水平方向に補間する ことにより三次元 $\mathrm{S}$ 波速度構造モデルを作成した。以 下,この三次元 $\mathrm{S}$ 波速度構造モデルから基盤の深度を決 定し, 埋没谷の形状を推定することを試みる。第14四 や第15図に示した微動アレイ探査の結果では，S波速 度は深度とともに滑らかに高くなっており，基盤深度 を特定することは難しい。一般に地表から行う物理探 査では, 探査深度とともに得られる結果の分解能や精 度は低下するので, 単独では地層境界などの深度を精 度良く決定することは難しい。そこで, 第15罒に示し たPS検層の結果を合わせて解釈を行った。検層を行っ たボーリング孔に抏いて沖積層の基底礫層の上面深度 は48.9 mである (石原ほか, 2004)。微動アレイ探査の 結果得られた $\mathrm{S}$ 波速度構造モデルでは,この深度付近で $\mathrm{S}$ 波速度が $250 \mathrm{~m} / \mathrm{s}$ から $280 \mathrm{~m} / \mathrm{s}$ に高くなる。そこで， 得られた三次元 $\mathrm{S}$ 波速度構造モデルに扎いて, $\mathrm{S}$ 波速度 が $250 \mathrm{~m} / \mathrm{s}$ を超える深度を抜き出し，これを基盤の深 度（沖積層の下面。ただし基底碟層が存在する場合は その上面）と考える。最初に述べたように一般に基盤 のS波速度としては300～400 m/sを目安とするが前述 のように本調査においては, 深部のS 波速度が低めに求 まっている可能性があり, 基盤のS 波速度の境界值とし て $250 \mathrm{~m} / \mathrm{s}$ を採用した。第16図に小規模微動アレイ探 査から得られた三次元 $\mathrm{S}$ 波速度構造モデルにおいて, $\mathrm{S}$ 波速度が $250 \mathrm{~m} / \mathrm{s}$ を超える深度, すなわち推定した基
盤深度の分布を示す.

第17四に, 既存ボーリングデータから推定した沖積 層下面（ただし基底碟層が存在する場合はその上面） の深度（中西ほか, 2007）を平面的に補間して作成し た, 調査地の基盤の深度分布を示す. 微動アレイ探査 から推定した同深度（第16図）と既存ボーリングデー タから補間した深度（第17図）の比較を下記にまと める。

両図において，GS-SK-1 孔の北西側で急激に基盤深 度が浅くなっており，この付近に埋没谷と埋没段丘の 境界が存在すると思われる。この境界はGS-SK-1孔の 北側 $1.5 \mathrm{~km}$ ほどで西側に大きく湾曲しているが, この 傾向も両図で一致している。埋没谷の東縁は調査地の 東端付近に存在しているが, この東縁の境界の形状も 両図で打打むね一致している，GS-SK-1孔の南西 $1 \mathrm{~km}$ 付近には, 北西一南東方向に小さな埋没谷が存在する ことも，両図で一致している。埋没谷内における基盤 深度は小規模微動アレイ探査の結果では40〜5 $\mathrm{m}$ であ るのに対して, 既存ボーリングでは $50 \mathrm{~m}$ 以深の範囲が 多く, 後者の方がやや深くなっている。一方, 埋没段 丘上の基盤深度は小規模微動アレイ探査の結果では 20 〜30 mであるのに対して, 既存ボーリングでは $10 \mathrm{~m}$ 以 浅の場所もあり, 後者の方がやや浅くなっている。こ のように微動アレイ探査は，基盤深度の推定について は10〜20 m程度の䛊差を含むものの, 埋没谷の分布範 囲についてはほぼ正確に推定することができたといえ る。したがって, ボーリングと比較した測定の簡便性 を考慮すれば, 微動アレイ探査は概略の地盤構造を推 定する手法として大変有効であると考えられる。本調 查に打いて微動アレイ探查の主目的は, 基盤の深度や $\mathrm{S}$ 波速度を正確に推定することではなく埋没谷の概略の 分布形状を把握することであるが,第16図と第17罒の 
No. 1 to 10

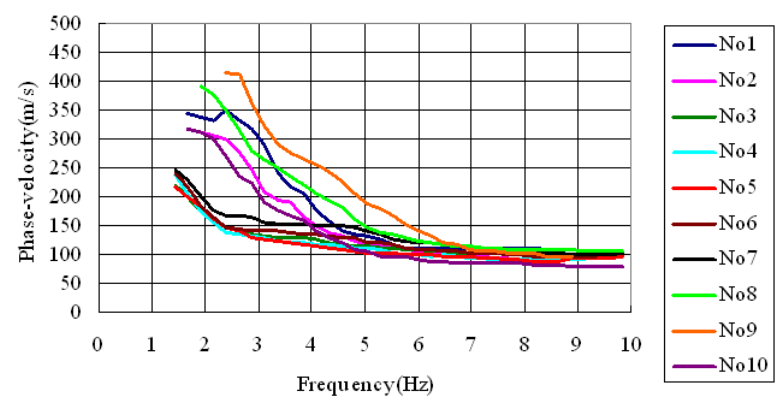

No. 21 to 30

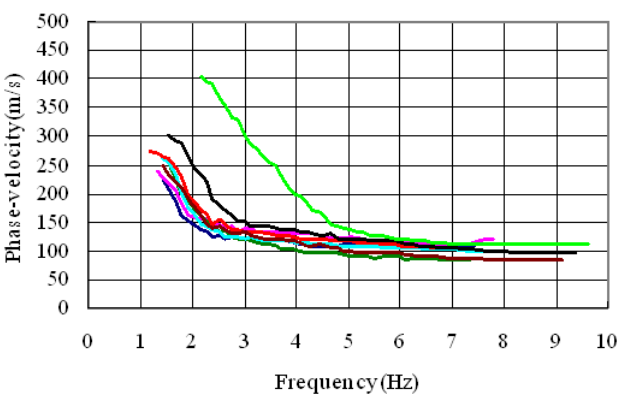

No. 41 to 50

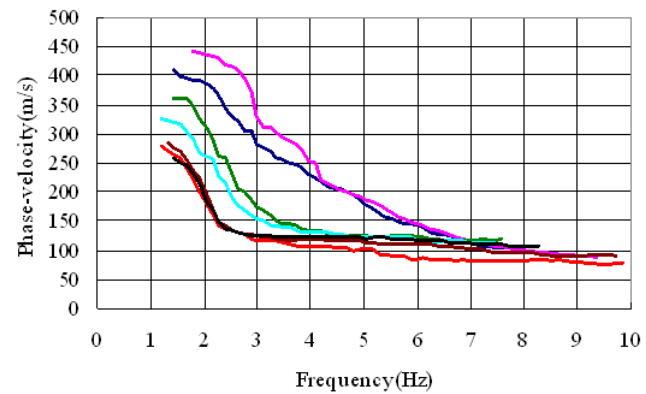

No. 61 to 70

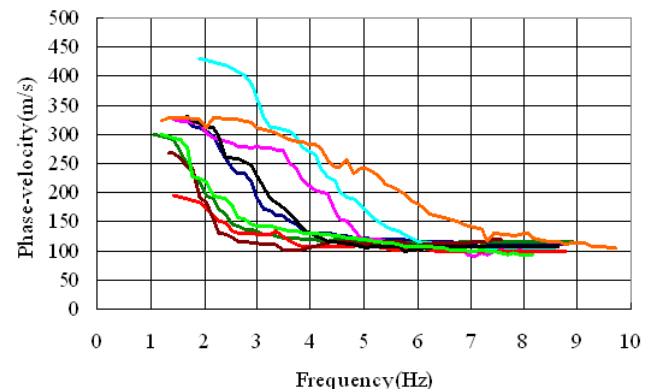

No.11 to 20

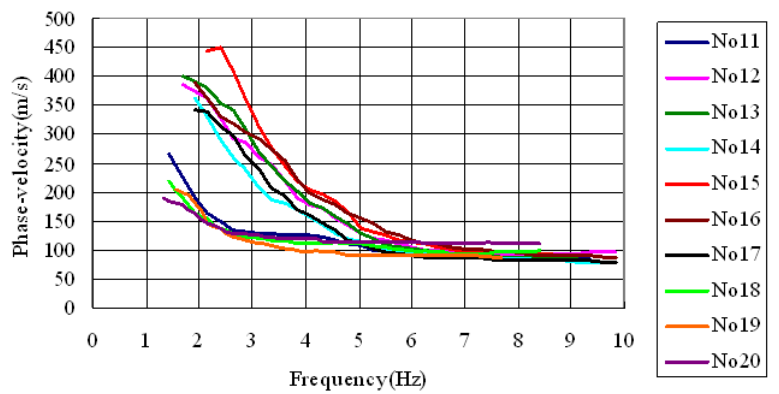

No. 31 to 40

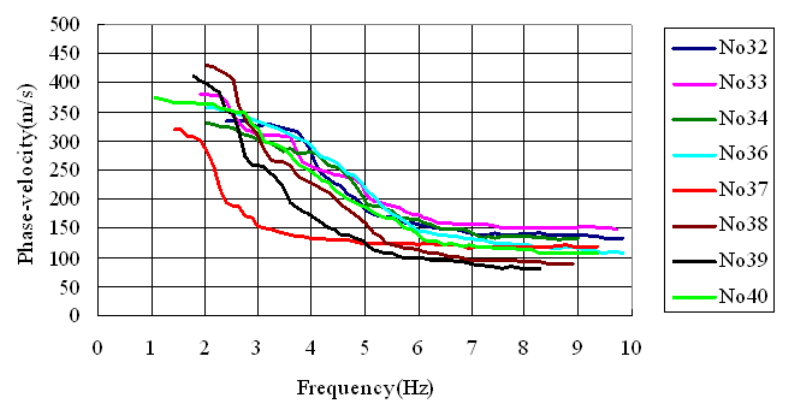

No. 51 to 60
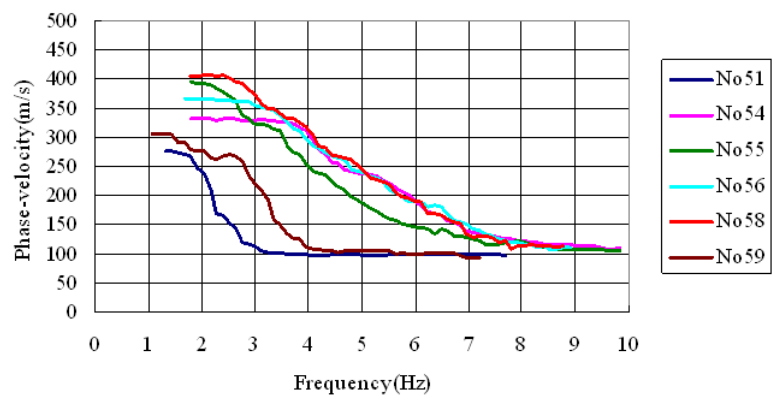

No. 71 to 80

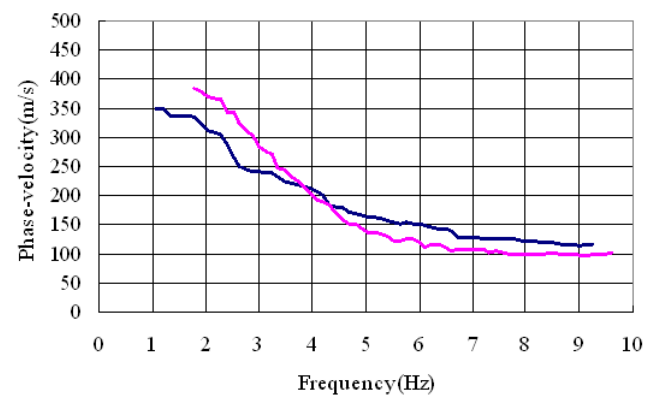

$-\mathrm{No}^{7} 1$ $-\mathrm{No} 72$

第13図 測定を行った 104 地点の全ての分散曲線.

Fig. 13 Dispersion curves for all 104 measurement points. 
No.101 to 110

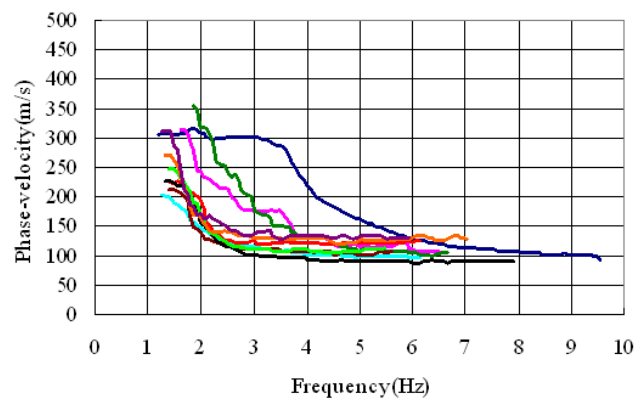

No. 121 to 130

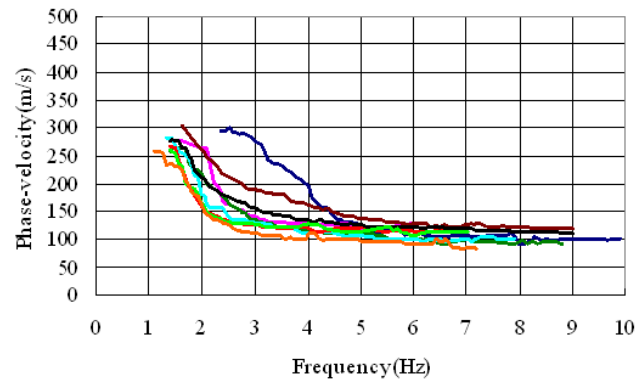

No.141 to 150

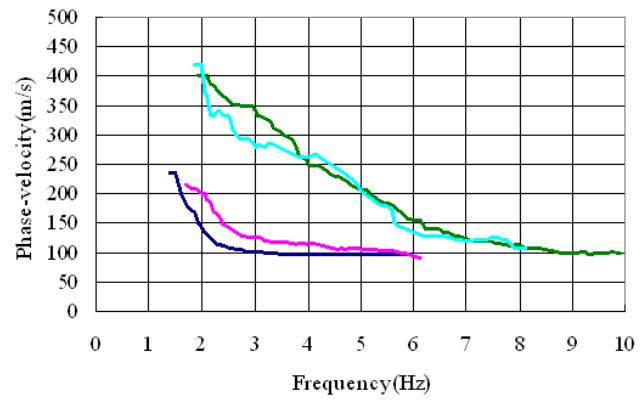

比較から微動アレイ探査は十分調査目的を満足したと いえる。

前述のように小規模微動アレイ探査単独では，基盤 の深度を特定することは困難であるが，ボーリングや 検層など他の情報と合わせて解釈することにより，広 範囲の基盤深度の分布を簡便に把握することができた といえる。

\section{6. まとめ}

関東地方の市街地に位置する $6 \mathrm{~km} \times 4 \mathrm{~km}$ のテスト フィールドに打いて, 約 100 点の小規模微動アレイ探査
No.111 to 120

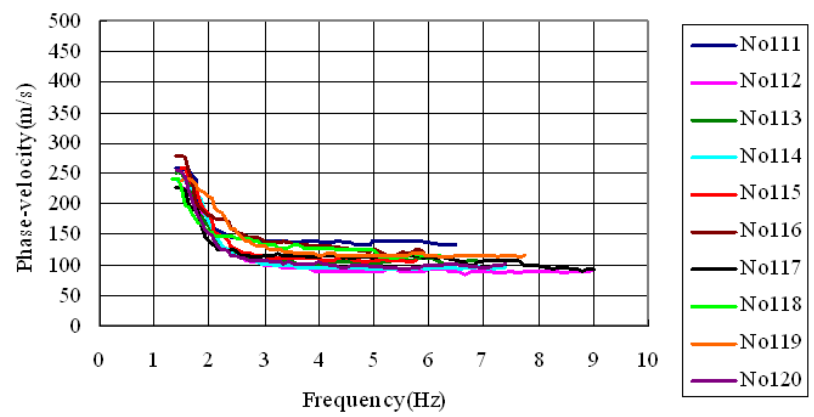

No.131 to 140

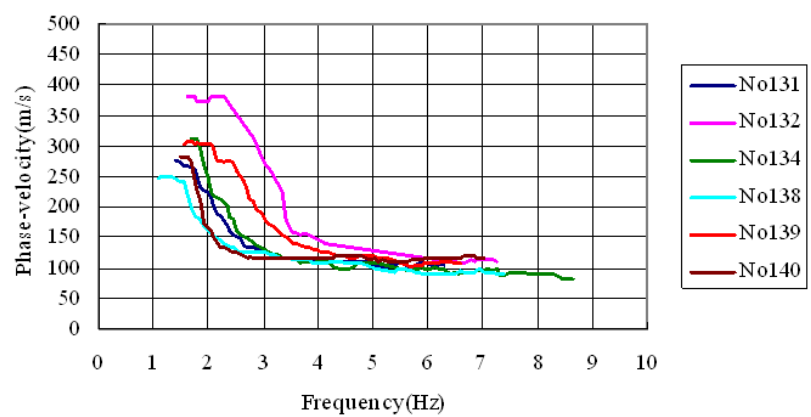

No. 151 to 160

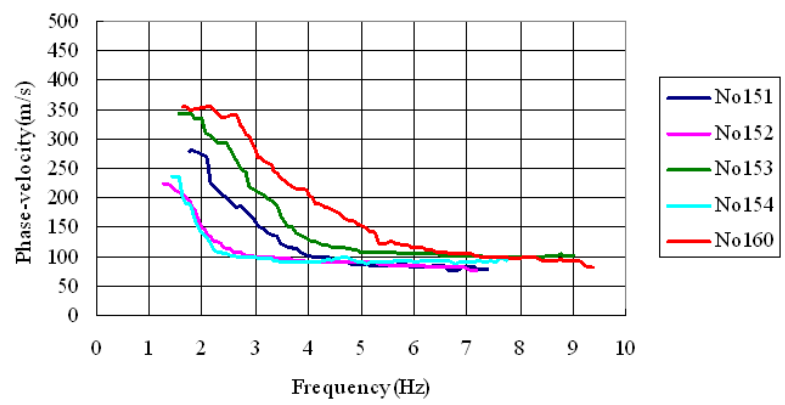

を行った結果, 既存のボーリングデータから推定され る地盤構造と調和する $\mathrm{S}$ 波速度構造モデルが得られた。 これは, 本地域においては沖積層・更新統境界が明瞭 な物性 $(\mathrm{S}$ 波速度) 境界となっていることを意味し，小 規模微動アレイ探査が埋没谷の分布を把握するうえで 有効な手法となることを示唆する。本論文に示した解 析はほぼ自動的に行っており, 初期モデルの作成やイ ンバージョンに打いて既知情報は一切使っていない。 したがって，既存のボーリングから得られた地盤情報 などを既知情報として解析に用いれば，より精度の高 いS波速度構造モデルが得られると思われる。本調査地 では今後も微動アレイ探査を行って, より広い範囲の 


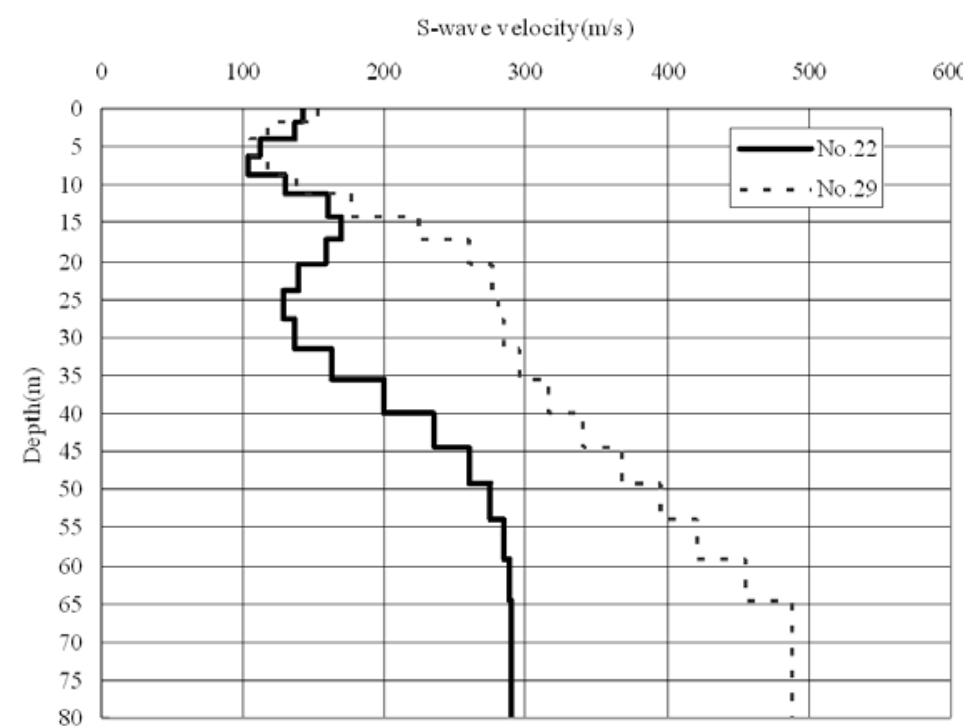

第14四 埋没谷内の No.22（実線）と埋没段丘上 のNo.29 (破線) のS 波速度構造の比較.

Fig. 14 Comparison of S-wave velocity model obtained at buried channel (No.22: top) and buried terrace (No.29 : bottom).

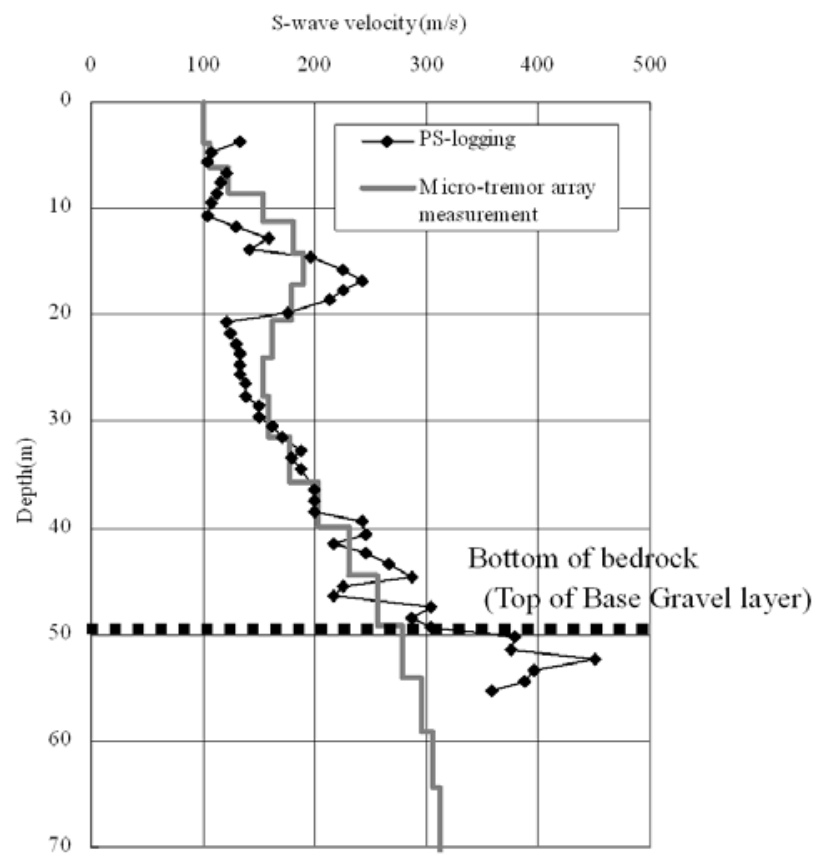

第15困ＧS-SK-1地点のPS検層結果とNo. 7 の地点の微動ア レイ探査の S 波速度構造の比較.

Fig. 15 Comparison of PS logging at the GS-SK-1 and S-wave velocity model obtained through the micro-tremor array measurements at No.7.

$\mathrm{S}$ 波速度構造モデルを構築していく予定であるが,併せ てボーリングのデータなどを利用した解析なども行い， 更に高精度の地盤モデルを作っていきたいと考えてい る。今後は東京や大阪などの大都市の中心部では多く のボーリングが行われているので，これらのボーリン グデータを収集することにより，概略の基盤深度分布 を推定することも可能である。しかし，既存のボーリ ングデータが十分ではない郊外の住宅地や地方都市で
は，地盤構造が全くわからない場合も多い。小規模微 動アレイ探查はこのような既存の地盤情報の乏しい地 域に打いて, 一次調査として概略の地盤構造を把握す るには大変効果的であると思われる。特に，小規模微 動アレイ探査によって得られるのは地盤のS波速度構造 であるため, 地盤の地震動に対する特性を評価する上 では大変有効である。今後も適用例を増やし, 都市域 に打ける大深度地盤を対象とした効率的な地盤調查手 法として確立していきたい.

謝辞：産業技術総合研究所の木村克己博士には本論文 を投稿する機会を与えて頂き, また多くの適切なご指 摘を頂きました。応用地質株式会社の齋藤正德博士， 産業技術総合研究所の田辺晋博士には多くの適切なご 指摘を頂きました。モニ一物探株式会社, 株式会社 日本メジャーサーヴェイの皆様には測定作業に協力し て頂きました，以上の皆様に心より打礼を申し上げ ます。

\section{文 献}

Aki, K. (1957) Space and time spectra of stationary stochastic waves, with special reference to microtremors. Bull. Earthq. Res. Ins., 35, 415456.

遠藤邦彦・小杉正人・菱田 量 (1988) 関東平野の沖 積層とその基底地形. 日本大学文理学部自然科学 研究所研究紀要, no.23, 37-48.

林 宏一(2004)表面波を用いた地下浅層部の探査. 非 破壞検査, 53, 254-259.

林 宏一・鈴木晴彦 (2003) 二次元表面波探查の地盤 

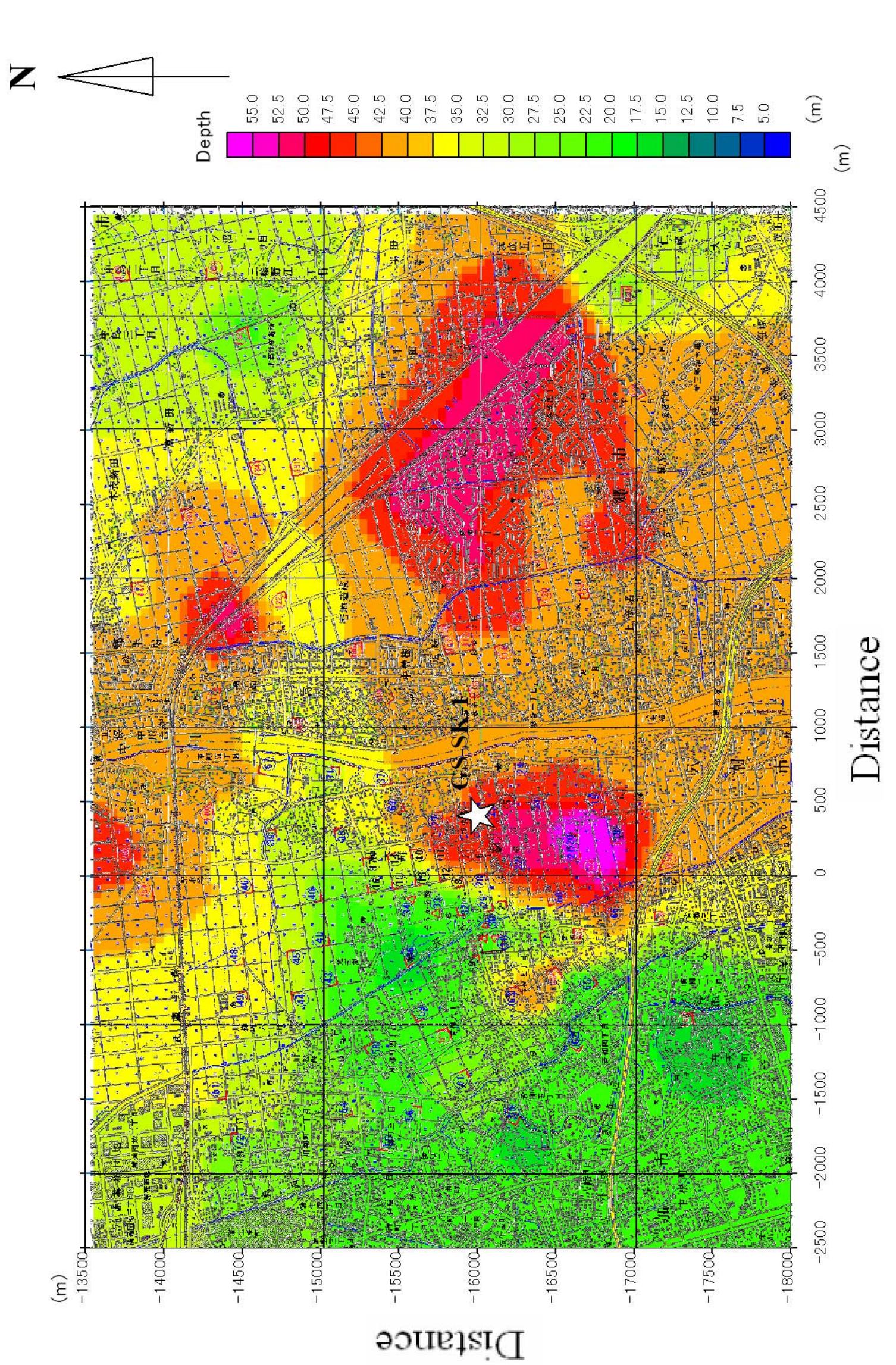

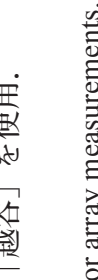
: 

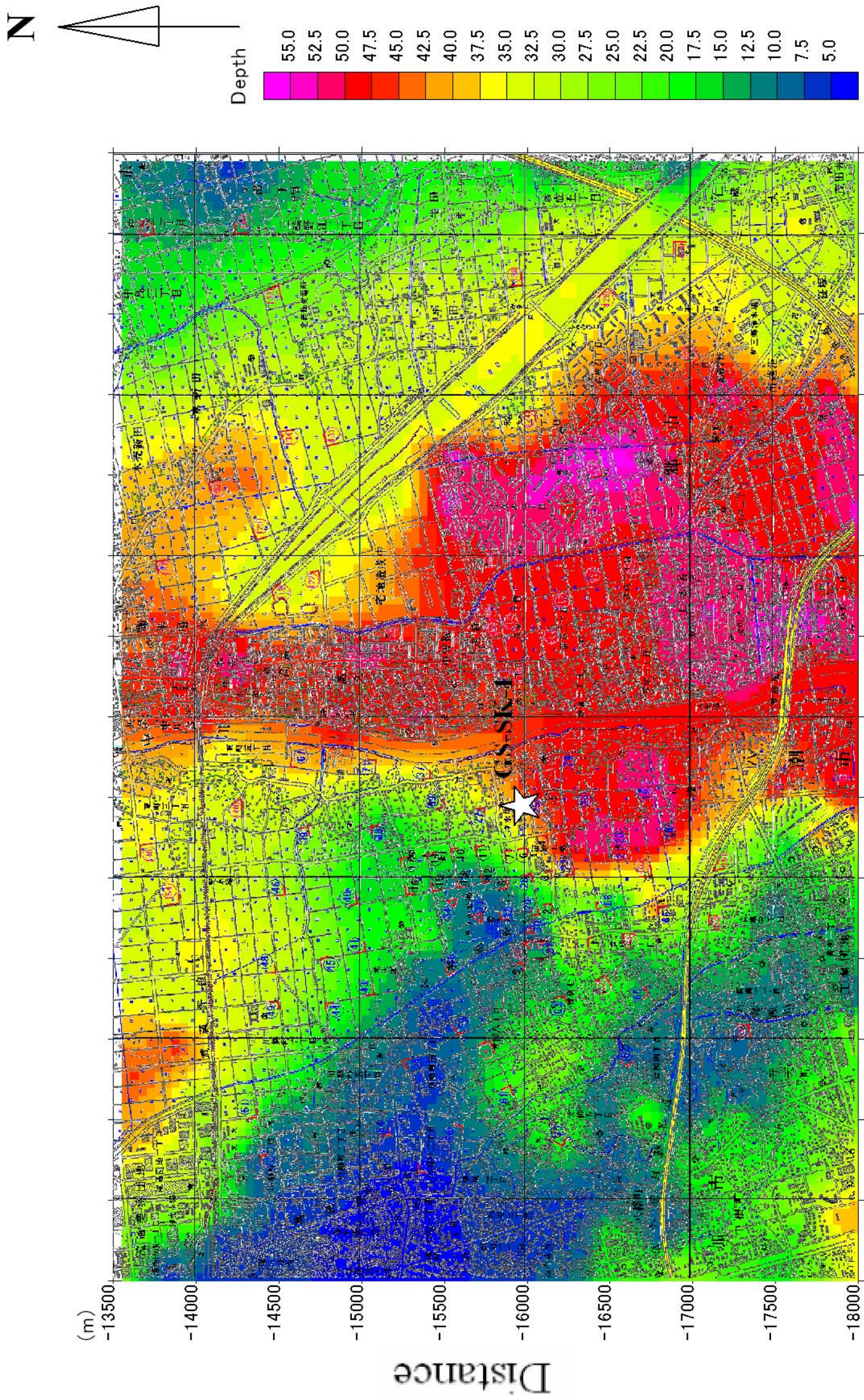
調査への適用. 第38回地盤工学研究発表会, 33-34. Hayashi, K. and Suzuki, H. (2004) CMP cross-correlation analysis of multi-channel surface-wave data. Exploration Geophysics, 35, 7- 13.

Hayashi, K., Matsuoka, T. and Hatakeyama, T. (2005) Joint analysis of a surface-wave method and micro-gravity survey. Journal of Environmental and Engineering Geophysics, 10, 175-184. 石原与四郎・ 木村克己·田辺 晋·中島 礼·宮地良典· 堀 和明・稲崎富士・八戸昭一 (2004) 埼玉県草 加市柿木地区で掘削された沖積層ボーリングコア (GS-SK-1)の堆積相・堆積物物性と放射性炭素年 代. 地質調査研究報告, 55, 183-200.

木村克己 (2004) 巻頭言：都市地質研究の展開. 地質 調査研究報告, 55, 181-182.

Louie, J.N. (2001) Faster, better : Shear-wave velocity to $100 \mathrm{~m}$ depth from refraction microtremor arrays. Bulletin of Seismological Society of America, 91, 347-364.

諸井孝文・武村雅之 $(2002)$ 関東地震 (1923 年 9 月 1 日) による木造住家被害データの整理と震度分布の推 定。日本地震工学会論文集, 2, no.3, 35-71.

中西利典·石原与四郎・田辺 晋・木村克己·八戸昭一 稲崎富士（準備中）ボーリング柱状図資料の解釈 による中川低地南部の沖積層基底困。地質調査総 合センター, 研究資料集.

日本道路協会（1996）道路橋示方書·同解説 V 耐震設 計編.

岡田 廣・坂尻直巳（1983）やや長周期微動による地 下構造の推定. 北海道大学地球物理学研究報告, 42, 112-143.

岡田 廣 - 松島 健 · 森谷武男 ·笹谷 努 (1990) 広 域・深層地盤調查のための長周期微動探査法. 物 理探査 $\mathbf{4 3}, 402-417$.
Park, C. B., Miller, R. D. and Xia, J. (1999) Multimodal analysis of high frequency surface waves. Proceedings of the symposium on the application of geophysics to engineering and environmental problems 99, 115-121.

齋藤正徳・椛沢宏之（1993）成層構造に対する反射率, 表面波分散曲線の計算 II .レーリー波の計算。物 理探査 46, 283-298.

境 有紀 - 津野靖士 - 工藤一嘉 - 壁谷澤寿海 (2004) 改 正建築基準法の解放工学的基盤波を想定した表層 地盤増幅特性の簡便評価法. 日本建築学会構造系 論文集 , 565, 73-783.

鈴木晴彦・林 宏一・伊集院博（2002）微動アレイ探 査および人工振源を用いた表面波探査による S波 速度構造の推定. 物理探査学会第107回学術講演 会講演論文集, 67-70.

武村雅之・諸井孝文（2002）地質調査所データに基づ く 1923 年関東地震の詳細震度分布 その 2 . 埼玉 県. 日本地震工学会論文集 , 2, no.2, 55-73.

Xia, J., Miller, R. D. and Park C. B. (1999) Configuration of near-surface shear-wave velocity by inverting surface wave. Proceedings of the symposium on the application of geophysics to engineering and environmental problems 99, 95-104.

横井俊明・林 宏一・青池邦夫 (2006) SPAC法におけ る複素コヒーレンス関数の方位依存性に関する ケース・スタディ。物理探査学会第 114 回学術講演 会講演論文集, 138-141.

吉村智昭 · 内山泰生 · 日比野浩 ·八代和彦 (2004) 表 面波探査結果を用いたKiK-net 日野観測点の地震 波増幅特性の検討 その 2 二次元FEMによる地 震波増幅特性の検討。2003年建築学会学術講演梗 概集, B-2, 653-654.

(受付： 2006 年 8 月 21 日；受理：2006 年 12 月 19 日) 